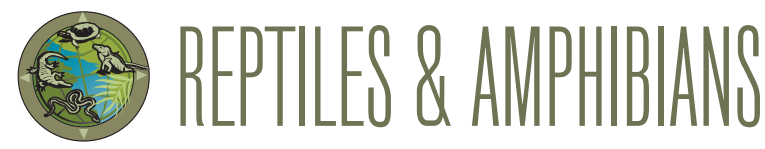

\title{
Herpetofauna of Sinhagad Forest Region, Northern Western Ghats, India
}

\author{
Anish Pardeshi ${ }^{1}$, Rohan V. Joglekar ${ }^{2}$, and Chaitanya S. Shukla ${ }^{3}$
}

\begin{abstract}
${ }^{1}$ Vanari 498, Aditya Residency, Mitramandal Chowk, Parvati, Pune-411009, Maharashtra, India (anishpardeshi103@gmail.com [corresponding author]) ${ }^{2}$ School of Science, Engineering and Environment, University of Salford, Manchester, Maxwell Building, 43 Crescent, Salford M5 4WT, United Kingdom; Bhagyachintamani Society, Paud Road, Kothrud, Pune-411038, Maharashtra, India (rvjwildlife@gmail.com)
\end{abstract}

${ }^{3}$ Kanchanganga Society, behind Gultekdi Market Yard, Bibwewadi-Kondhwa Road, Gultekdi, Pune-411037, Maharashtra, India (shukla.chaitanya@gmail.com)

A mphibians and reptiles are among the world's most threatened vertebrates (Bohm et al. 2013; Catenazzi 2015). Declines in herpetofaunal species have been caused by a variety of factors that include loss of habitat, climate change, overexploitation, water pollution, and the emergence of diseases (Gibbons et al. 2000; Kiesecker et al. 2001; Stuart et al. 2004; Araujo et al. 2006; Pounds et al. 2006; Sodhi et al. 2008; Ramesh et al. 2013; Thomas and Biju 2015; Nowakowski et al. 2017). The Indian herpetofauna, with 432 species of amphibians and 572 species of reptiles (Aengals et al. 2018; Dinesh et al. 2019), has not been immune to these threats.

Pune District, Maharashtra, India, in the northern Western Ghats, is home to 31 amphibian and 23 reptilian species (Khaire and Khaire 1985; Padhye et al. 2002). Herein we present an annotated checklist of herpetofauna of the Sinhagad Forest Region (18²1'56.39"N, 7345'18.97"E; Fig. 1) in Pune District and address threats to herpetofauna in the area.

The Sinhagad Forest Region has an average annual temperature of $25.0^{\circ} \mathrm{C}$ and an average annual rainfall of 763

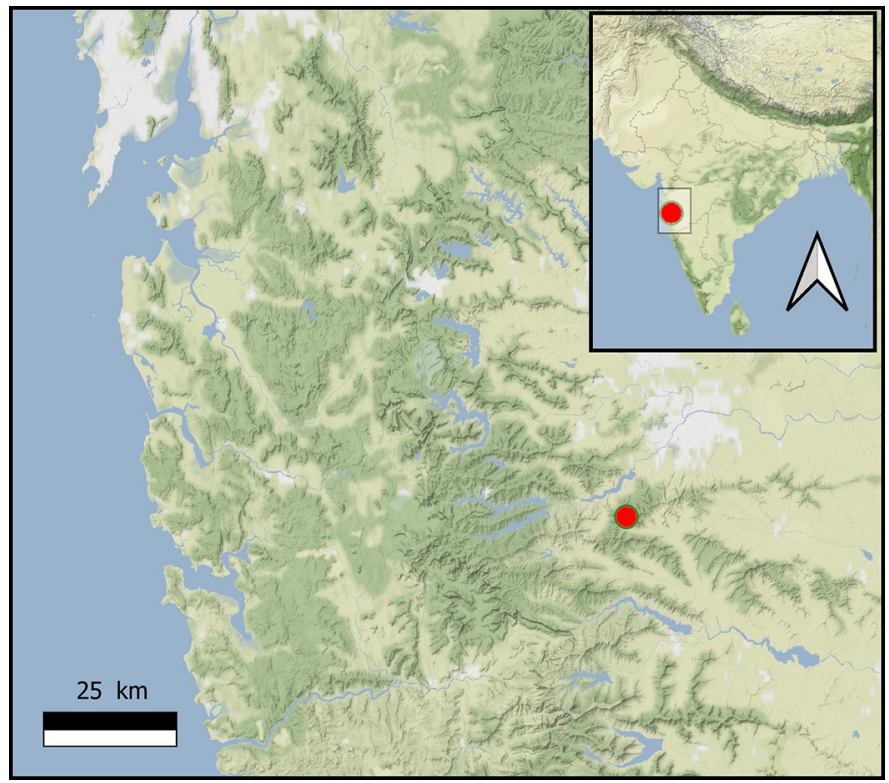

Fig. 1. Map showing the location of the Sinhagad Forest Region (red dots) in the northern Western Ghats of Pune District, Maharashtra, India.

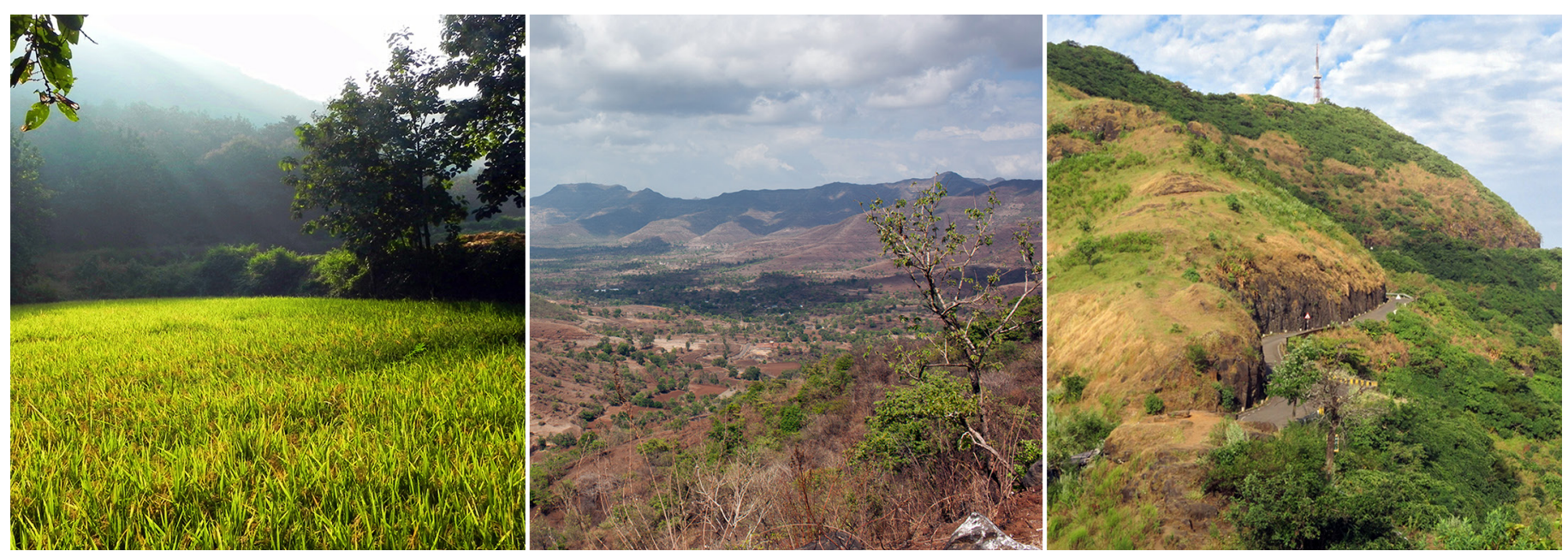

Fig. 2. Habitats sampled in the Sinhagad Forest Region, Pune District, Maharashtra, India: agricultural fields (left), tropical dry deciduous forest (center), and hilltop plateaus (right). Photographs by Sandeep Bapat (left and right) and Chaitanya S. Shukla (center). 
Table 1. Checklist of herpetofauna in the Sinhagad Forest Region, Maharashtra, India. Abbreviations: Habitat (DF = deciduous forest, $\mathrm{AG}=$ agricultural fields, $\mathrm{HP}=$ hill plateau, $\mathrm{AQ}=$ aquatic [ponds, puddles, streams]); status $(\mathrm{C}=$ common, $\mathrm{U}=\mathrm{uncommon}, \mathrm{R}=$ rare $) ; \mathrm{IUCN}$ Red List Assessment (EN = Endangered, VU = Vulnerable, LC = Least Concern, DD = Data Deficient; NA = Not Assessed).

IUCN Red

\begin{tabular}{|c|c|c|c|}
\hline Species & Habitat & Abundance & List Status \\
\hline \multicolumn{4}{|l|}{ AMPHIBIA: ANURA } \\
\hline \multicolumn{4}{|l|}{ Bufonidae } \\
\hline \multicolumn{4}{|l|}{ Dicroglossidae } \\
\hline Indian Skipper Frog (Euphlyctis cyanophlyctis) & $\mathrm{AG}, \mathrm{AQ}$ & $\mathrm{C}$ & LC \\
\hline Syhadra Cricket Frog (Minervarya syhadrensis) & $\mathrm{HP}, \mathrm{AG}$ & $\mathrm{C}$ & LC \\
\hline Western Burrowing Frog (Sphaerotheca pashchima) & $\mathrm{HP}, \mathrm{AG}$ & $\mathrm{U}$ & NA \\
\hline \multicolumn{4}{|l|}{ Microhylidae } \\
\hline Indian Balloon Frog (Uperodon globulosus) (Fig. 3A) & $\mathrm{AG}, \mathrm{AQ}$ & $\mathrm{C}$ & LC \\
\hline Wide-spread Fungoid Frog (Hydrophylax bahuvistara) & $\mathrm{DF}, \mathrm{HP}, \mathrm{AQ}$ & $\mathrm{C}$ & NA \\
\hline \multicolumn{4}{|l|}{ Ranixalidae } \\
\hline Leith’s Leaping Frog (Indirana leithii) & DF, HP & $\mathrm{C}$ & $\mathrm{VU}$ \\
\hline \multicolumn{4}{|l|}{ Rhacophoridae } \\
\hline Common Indian Treefrog (Polypedates maculatus) (Fig. 3B) & DF & $\mathrm{C}$ & $\mathrm{LC}$ \\
\hline Ghate's Shrub Frog (Raorchestes ghatei) (Fig. 3C) & DF, HP & $\mathrm{C}$ & NA \\
\hline
\end{tabular}

\section{REPTILIA: TESTUDINES}

\section{Trionychidae}

Indian Flapshell Turtle (Lissemys punctata)

AQ $\quad$ R $\quad$ LC

\section{REPTILIA: SQUAMATA (lizards)}

\section{Agamidae}

Indian Garden Lizard (Calotes versicolor)

$\mathrm{DF}, \mathrm{AG}$

$\mathrm{DF}$

Roux's Forest Lizard (Calotes rouxii)

Flat-headed Fan-throated Lizard (Sitana laticeps)

\section{Gekkonidae}

Deccan Ground Gecko (Cyrtodactylus deccanensis)

$\mathrm{HP}$

DF

C NA

Spotted Leaf-toed Gecko (Hemidactylus maculatus)

Murray's House Gecko (Hemidactylus murrayi)

Leschenault's Leaf-toed Gecko (Hemidactylus leschenaultii)

$\mathrm{HP}-\mathrm{R}$

$\mathrm{U}$

LC

\section{Lygosomidae}

Günther's Supple Skink (Riopa guentheri)

Lined Supple Skink (Riopa lineata)

Spotted Supple Skink (Riopa punctata)

\section{Mabuyidae}

Common Keeled Skink (Eutropis carinata)

\begin{tabular}{ccc} 
DF, HP & C & LC \\
DF & U & LC \\
DF, HP, AG & C & NA \\
DF & R & NA \\
\hline DF & U & LC \\
DF & U & LC \\
DF, HP & U & NA
\end{tabular}

DF, AG U $\quad$ LC


Species

Bengal Monitor (Varanus bengalensis)

Chamaeleonidae

Indian Chamaeleon (Chamaeleo zeylanicus)
Habitat

DF, HP

DF, HP

\section{REPTILIA: SQUAMATA (snakes)}

\section{Colubridae}

Black-eyed Vinesnake (Ahaetulla borealis)

Banded Racer (Argyrogena fasciolata)

Beddome's Catsnake (Boiga beddomei)

Common Catsnake (Boiga trigonata) (Fig. 4A)

Common Trinket Snake (Coelognathus helena)

Common Bronzeback (Dendrelaphis tristis)

Common Wolfsnake (Lycodon aulicus)

Barred Wolfsnake (Lycodon striatus)

Common Kukri Snake (Oligodon arnensis)

Russell's Kukri Snake (Oligodon taeniolatus fasciatus)

Oriental Ratsnake (Ptyas mucosa)

Duméril's Black-headed Snake Sibynophis subpunctatus)

\section{Elapidae}

Common Krait (Bungarus caeruleus) (Fig. 4B)

Slender Coralsnake (Calliophis melanurus)

Striped Coralsnake (Calliophis nigriscens)

Spectacled Cobra (Naja naja)

\section{Erycidae}

Common Sandboa (Eryx conicus)

Red Sandboa (Eryx johnii)

Lamprophiidae

Condanarus Sandsnake (Psammophis condanarus)

\section{Natricidae}

Striped Keelback (Amphiesma stolatum)

Checkered Keelback (Fowlea piscator) (Fig. 4C)

Green Keelback (Rhabdophis plumbicolor)

Pythonidae

Indian Rock Python (Python molurus)

Typhlopidae

Beaked Wormsnake (Grypotyphlops acutus)

Brahminy Wormsnake (Indotyphlos cf. braminus)

\section{Uropeltidae}

Large-scaled Shieldtail (Uropeltis macrolepis) (Fig. 4D)

Phipsons Shieldtail (Uropeltis phipsonii)

\section{Viperidae}

Indian Saw-scaled Viper (Echis carinatus)

Russell's Viper (Daboia russelii)

Bamboo Pitviper (Trimeresurus gramineus)
IUCN Red

List Status

Abundance

VU

C

LC

$\begin{array}{ccc}\text { DF } & \text { C } & \text { NA } \\ \text { HP } & \text { R } & \text { NA } \\ \text { DF } & \text { U } & \text { DD } \\ \text { DF } & \text { C } & \text { LC } \\ \text { DF } & \text { C } & \text { NA } \\ \text { DF } & \text { C } & \text { NA } \\ \text { DF } & \text { C } & \text { NA } \\ \text { DF, HP } & \text { U } & \text { NA } \\ \text { HP } & \text { U } & \text { NA } \\ \text { HP } & \text { R } & \text { LC } \\ \text { DF, HP } & \text { C } & \text { NA } \\ \text { DF } & \text { R } & \text { NA }\end{array}$

$\begin{array}{cll}\text { DF, HP } & \text { C } & \text { NA } \\ \text { DF } & \text { R } & \text { NA } \\ \text { DF } & \text { R } & \text { LC } \\ \text { HP, AG } & \text { C } & \text { LC }\end{array}$

$\begin{array}{cll}\text { DF, HP } & \text { U } & \text { NA } \\ \text { AG } & \text { R } & \text { NA }\end{array}$

DF $\quad$ R

$\begin{array}{cll}\text { HP, AG } & \text { C } & \text { NA } \\ \text { DF, AQ } & \text { C } & \text { NA } \\ \text { DF } & \text { C } & \text { NA }\end{array}$

$\begin{array}{lll}\text { DF } & \text { R }\end{array}$

$\begin{array}{lll}\text { DF, AG } & \text { C } & \text { LC } \\ \text { DF, AG } & \text { U } & \text { LC }\end{array}$

$\begin{array}{lll}\text { DF, HP } & \text { U } & \text { LC } \\ \text { AG, HP } & \text { U } & \text { VU }\end{array}$

$\begin{array}{cll}\text { HP } & \text { U } & \text { NA } \\ \text { DF, AG } & \text { C } & \text { LC } \\ \text { DF, HP } & \text { C } & \text { LC }\end{array}$



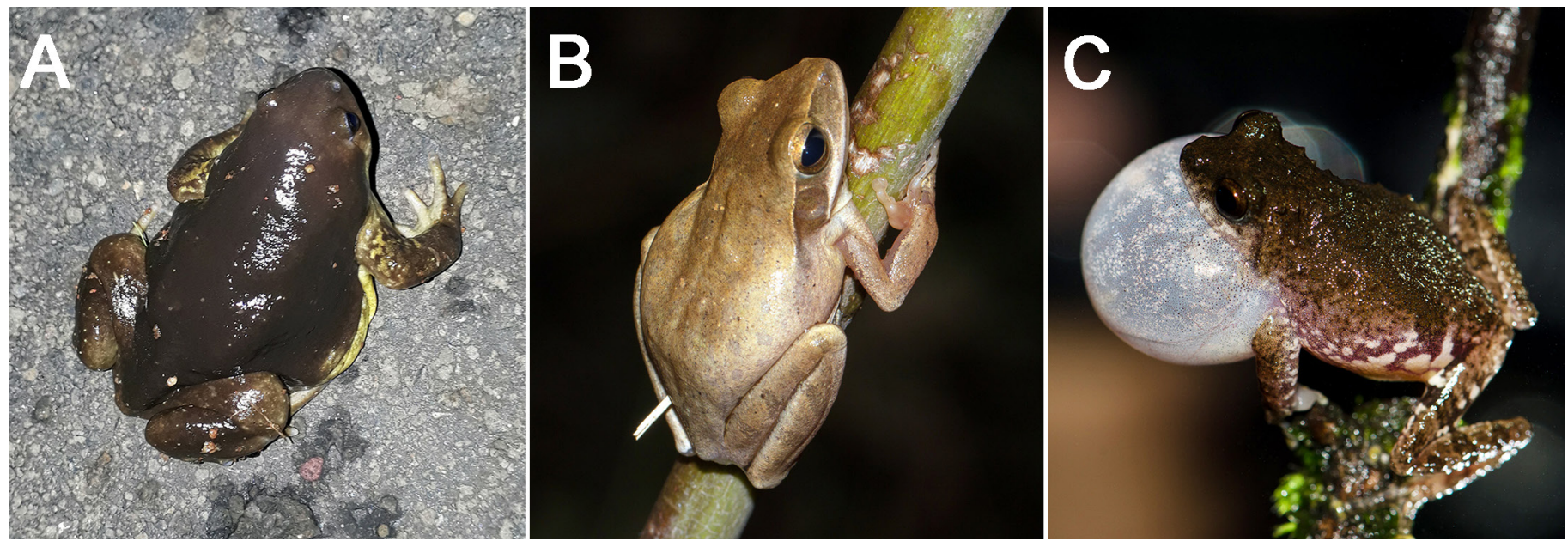

Fig. 3. Three amphibian species encountered during surveys in the Sinhagad Forest Region, Pune District, Maharashtra, India: Indian Balloon Frog (Uperodon globulosus) (A), Common Indian Treefrog (Polypedates maculatus) (B), and Ghate's Shrub Frog (Raorchestes ghatei) (C). Photographs by Chaitanya S. Shukla.
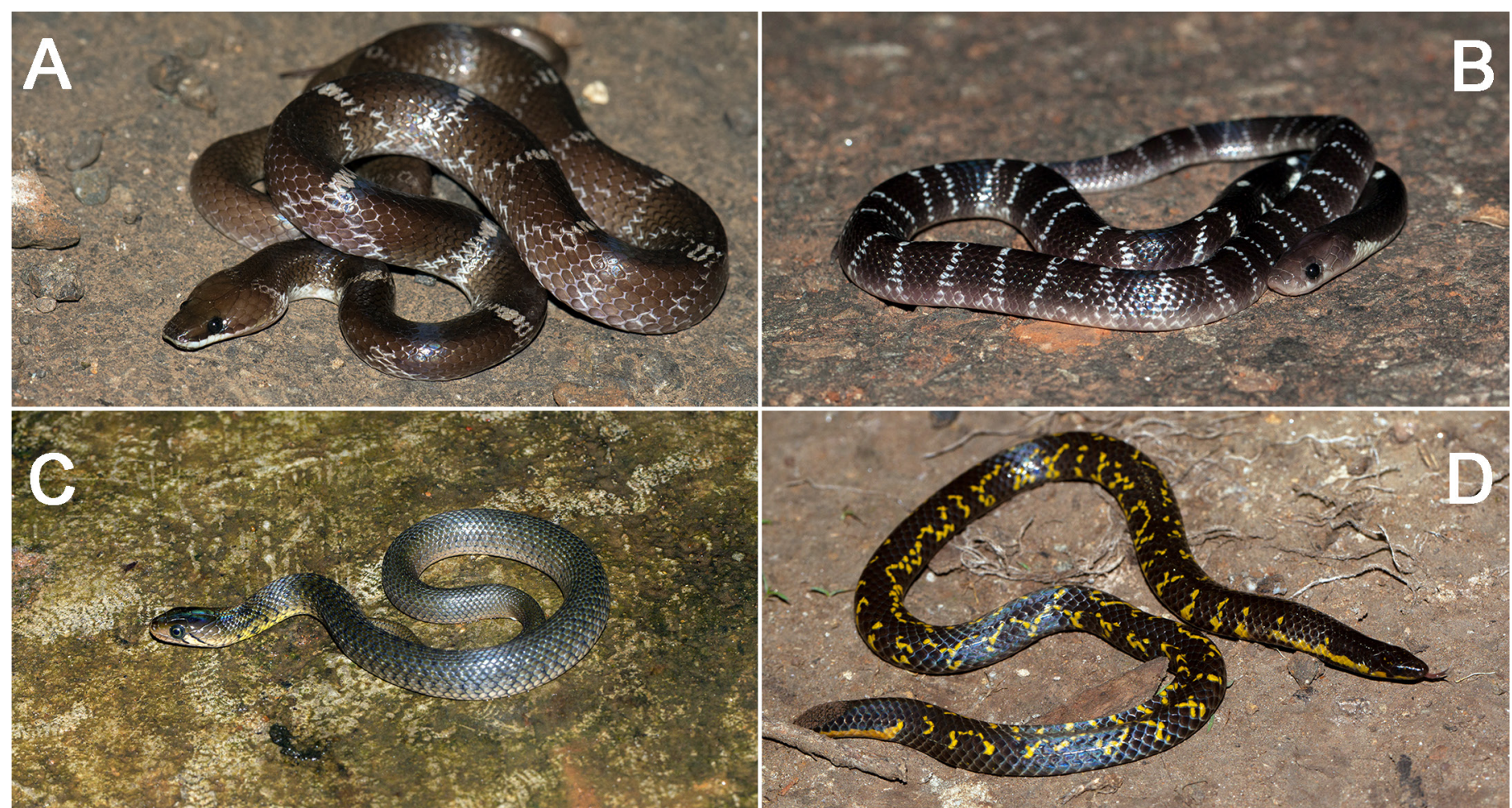

Fig. 4. Four reptilian species encountered during surveys in the Sinhagad Forest Region, Pune District, Maharashtra, India: Common Catsnake (Boiga trigonata) (A), Common Krait (Bungarus caeruleus) (B), Checkered Keelback (Fowlea piscator) (C), and Large-scaled Shieldtail (Uropeltis macrolepis) (D). Photographs by Chaitanya S. Shukla.

mm (https://en.climate-data.org/asia/india/maharashtra/ pune-31/\#temperature-graph). The high rainfall creates an abundance of temporary puddles, ponds, and streams during the monsoon and post-monsoon seasons. The principal natural habitat is tropical dry deciduous forest (Ranadive et al. 2013), but planted Teak (Tectona grandis) is abundant. The mouth of the valley has been converted into paddy fields. The uplands are dominated by hilltop plateaus.
From January 2018 to December 2019, we conducted active visual searches for reptiles and amphibians during an average of ten days per month. We searched leaf litter, rocky outcrops, under rocks, on tree trunks, along various aquatic habitats (e.g., streams, ponds, temporary puddles) in agricultural fields, forested areas, and hilltop plateaus (Fig. 2), and identified amphibians and reptiles using guidebooks by Daniel (2002), Whitaker and Captain (2008), and Gururaja 


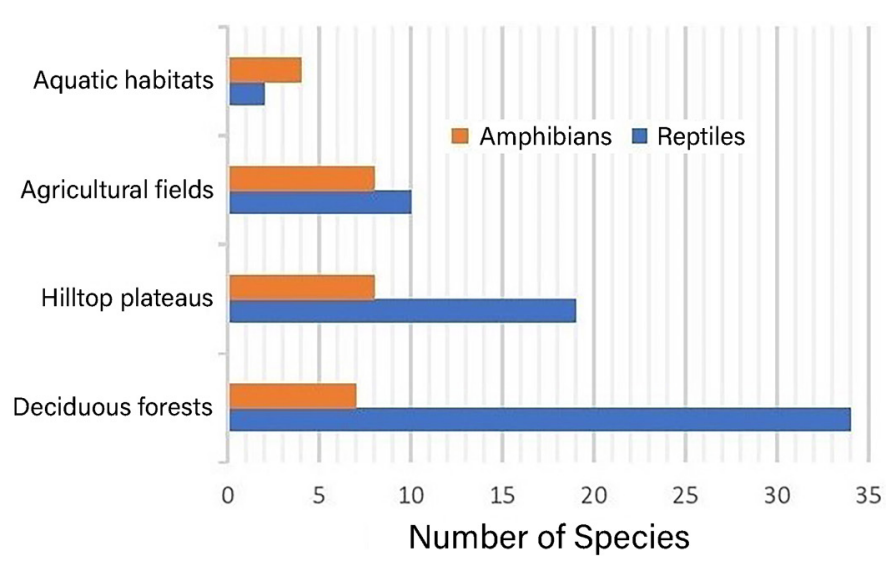

Fig. 5. Number of species of amphibians and reptiles in various sampled habitats in the Sinhagad Forest Region, Pune District, Maharashtra, India.

(2012). We also interviewed wildlife researchers, wildlife enthusiasts, and local people, and included their observations in a checklist of species in the area (Table 1).

We recorded a total of 57 species in 22 families, 44 species of reptiles in 16 families and 13 species of amphibians in six families. Amphibians were found in approximately equal numbers in each of the four major habitats, whereas reptiles were most abundant in deciduous forest (Fig. 5).

The Marbled Ramanella (Uperodon mormoratus), the only endangered species found during our study, was encountered exclusively in deciduous forest. The four vulnerable species - Leith's Leaping Frog (Indirana leithii), Bengal Monitor (Varanus bengalensis), Philipson's Shieldtail (Uropeltis phipsonii), and Indian Rock Python (Python molurus) - were mostly in deciduous forest and hilltop plateau habitats, with the Indian Rock Python found only in the densest forest patches and Philipson's Shieldtail also found in an agricultural field. This clearly indicates the importance of forested areas and the hilltop plateaus for the conservation of these Red-Listed species. Although already degraded by deforestation and conversion to agriculture (especially in the lowlands) and ongoing urbanization and development to support a growing tourist trade (Shinde 2017), a proposed roadway connecting the foothills to the upland fort is likely to fragment and further degrade these important habitats, posing a threat to both threatened species and those currently of least concern.

\section{Acknowledgements}

We thank the local villagers living in the vicinity of the Sinhagad Forest Region, and Varun Vaze for their contributions.

\section{Literature Cited}

Aengals, R., V.M.S. Kumar, M.J. Palot, and S.R Ganesh. 2018. A Checklist of Reptiles of India. Version 3.0. Online publication is available at www.zsi.gov. in.

Araujo, M.B., W. Thuiller, and R.G. Pearson. 2006. Climate warming and the decline of amphibians and reptiles in Europe. Journal of Biogeography 33:
1712-1728. https://doi.org/10.1111/j.1365.2699.2006.01482.x.

Böhm, M., B. Collen, J.E.M. Baillie, J. Chanson, N. Cox, G. Hammerson, M. Hoffmann, S.R. Livingstone, M. Ram, A.G.J. Rhodin, S.N. Stuart, P.P.1. van Dijk, B.E. Young, L.E. Afuang, A. Aghasyan, A.G. Aguayo, C. Aguilar, R. Ajtic, F. Akarsu, L.R.V. Alencar, A. Allison, N. Ananjeva, S. Anderson, C. Andrén, D. Ariano-Sánchez, J.C. Arredondo, M. Auliya, C.C. Austin, A. Avci, P.J. Baker, A.F. Barreto-Lima, C.L. Barrio-Amorós, D. Basu, M.F. Bates, A. Batistella, A. Bauer, D. Bennett, W. Böhme, D. Broadley, R. Brown, J. Burgess, A. Captain, S. Carreira, M. Castaneda, F. Castro, A. Catenazzi, J.R. Cedeño-Vázquez, D. Chapple, M. Cheylan, D.F. Cisneros-Heredia, D. Cogalniceanu, H. Cogger, C. Corti, G.C. Costa, P.J. Couper, T. Courtney, J. Crnobrnja-Isailovic, P.-A. Crochet, B. Crother, F. Cruz, J. Daltry, R.J.R. Daniels, I. Das, A. de Silva, L. Dirksen, T. Doan, K. Dodd, J.S. Doody, M.E. Dorcas, J. Duarte de Barros Filho, V.T. Egan, E.H. El Mouden, D. Embert, R.E. Espinoza, A. Fallabrino, X. Feng, Z.-J. Feng, L. Fitzgerald, O. Flores-Villela, F.G.R. França, D. Frost, H. Gadsden, T. Gamble, S.R. Ganesh, M.A. Garcia, J.E. García-Pérez, J. Gatus, M. Gaulke, P. Geniez, A. Georges, J. Gerlach, S. Goldberg, J.C.T. Gonzalez, D.J. Gower, T. Grant, E. Greenbaum, P. Guo, S. Haitao, A.M. Hamilton, K. Hare, B. Hedges, N. Heideman, C. Hilton-Taylor, R. Hitchmough, B. Hollingsworth, M. Hutchinson, I. Ineich, J. Iverson, F.M. Jaksic, R. Jenkins, U. Joger, R. Jose, Y. Kaska, J.S. Keogh, G. Köhler, G. Kuchling, Y. Kumluta, A. Kwet, E. La Marca, W. Lamar, A. Lane, B. Lardner, C. Latta, G. Latta, M. Lau, P. Lavin, D. Lawson, M. LeBreton, E. Lehr, D. Limpus, N. Lipczynski, A.S. Lobo, M.A. López-Luna, L. Luiselli, V. Lukoschek, M. Lundberg, P. Lymberakis, R. Macey, W.E. Magnusson, L. Mahler, A. Malhotra, J. Mariaux, B. Maritz, O.A.V. Marques, R. Márquez, M. Martins, G. Masterson, J.A. Mateo, R. Mathew, N. Mathews, G. Mayer, J.R. McCranie, J. Measey, F. MendozaQuijano, M. Menegon, S. Métrailler, D.A. Milton, C. Montgomery, S.A.A. Morato, T. Mott, A. Muñoz-Alonso, J. Murphy, T.Q. Nguyen, G. Nilson, C. Nogueira, H. Núñez, H. Ota, J. Ottenwalder, T. Papenfuss, S. Pasachnik, P. Passos, O.S.G. Pauwels, V. Pérez Mellado, N. Pérez-Buitrago, E.R. Pianka, J. Pleguezuelos, C. Pollock, P. Ponce-Campos, R. Powell, F. Pupin, G.E. Quintero Díaz, R. Radder, J. Ramer, A.R. Rasmussen, C. Raxworthy, R. Reynolds, N. Richman, E.L. Rico, E. Riservato, G. Rivas, P.L.B. Rocha, M.-O. Rödel, L. Rodríguez Schettino, W.M. Roosenburg, J.P. Ross, R. Sadek, K. Sanders, G. Santos-Barrera, H.H. Schleich, B. Schmidt, A. Schmitz, M. Sharifi, G. Shea, R. Shine, T. Slimani, R. Somaweera, S. Spawls, P. Stafford, R. Stuebing, S. Sweet, E. Sy, H. Temple, M. Tognielli, K. Tolley, P.J. Tolson, B. Tuniyev, S. Tuniyev, N. Üzüm, G. van Buurt, M. Van Sluys, A. Velasco, M. Vences, M. Veselý, S. Vinke, T. Vinke, G. Vogel, M. Vogrin, R.C. Vogt, O.R. Wearn, Y.L. Werner, M.J. Whiting, T. Wiewandt, J. Wilkinson, B. Wilson, S. Wren, T. Zamin, K. Zhou, and G. Zug. 2013. The conservation status of the world's reptiles. Biological Conservation 157: 372-385. https://doi.org/10.1016/j.biocon.2012.07.015.

Catenazzi, A. 2015. State of the world's amphibians. Annual Review of Environment and Resources 40: 91-119. https://doi.org/10.1146/annurev-environ-102014-021358.

Daniel, J.C. 2002. The Book of Indian Reptiles and Amphibians. Bombay Natural History Society, Mumbai, India.

Dinesh, K.P., C. Radhakrishnan, B.H. Channakeshavamurthy, P. Deepak, and N.U. Kulkarni. 2019. A Checklist of Amphibians of India with IUCN Conservation Status. Version 2.0. Online publication is available at www.zsi. gov.in.

Gibbons, J.W., D.E. Scott, T.J. Ryan, T.D. Buhlmann, B.S. Metts, J.L. Greene, T. Mills, Y. Leiden, S. Poppy, and C.T. Winne. 2000. The global decline of reptiles, déjà vu amphibians. BioScience 50: 653-666. https://doi. org/10.1641/0006-3568(2000)050[0653:TGDORD]2.0CO;2.

Gururaja, K.V. 2012. Pictorial Guide to Frogs and Toads of the Western Ghats. Gubbi Labs LLP, Bangalore, India.

Khaire, A. and N. Khaire. 1985. A list of snakes in the neighbourhood of Poona, Maharashtra with some observations. Geobios News Reports 4: 112-114.

Kiesecker, J.M., A.R. Blaustein, and L.K. Belden. 2001. Complex causes of amphibian population declines. Nature 410: 681-684. https://doi. org/10.1038/35070552.

Nowakowski, A.J., M.E. Thompson, M.A. Donnelly, and B.D. Todd. 2017. Amphibian sensitivity to habitat modification associated with population trends and species traits. Global Ecology and Biogeography 26: 700-712. https://doi.org/10.1111/geb.12571.

Padhye A.D., M. Mahabaleshwarkar, and H.V. Ghate. 2002. An overview of amphibian fauna of Pune district with special reference to their status in and around Pune city. Zoos' Print Journal 17: 757-763. 
Pounds, J.A., M.R. Bustamante, L.A. Coloma, J.A. Consuegra, M.P.L. Fogden, P.N. Foster, E.L. Marca, K.L. Masters, A. Merino-Viteri, R. Puschendorf, S.R. Ron, G.A. Sanchez-Azofeifa, C.J. Still, and B.E. Young. 2006. Widespread amphibian extinctions from epidemic disease driven by global warming. Nature 439: 161-167. https://doi.org/10.1038/nature04246.

Ramesh, T., K.J. Hussain, K.K. Satpathy, and M. Selvanayagam. 2013. Community composition and distribution of herpetofauna at Kalpakkam Nuclear campus, Southern India. Herpetology Notes 6: 343-351.

Ranadive, K.R., P.K. Jite, V.D. Ranade, and J.G. Vaidya. 2013. Flora of Aphyllophorales from Pune District-Part I. Journal on New Biological Reports 2: 188-227.

Shinde, A.S. 2017. A geographical analysis of major tourist attraction in Pune District, Maharashtra State. International Journal of Researches in Social
Sciences and Information Studies 5: 41-44.

Sodhi, N.S., D. Bickford, A.C. Diesmos, T.M. Lee, L.P. Koh, B.W. Brook, C.H. Sekercioglu, and C.J.A. Bradshaw. 2008. Measuring the meltdown: drivers of global amphibian extinction and decline. PLoS ONE 3: e1636. https://doi. org/10.1371/journal.pone.0001636.

Stuart, S.N., J.S. Chanson, N.A. Cox, B.E. Young, A.S.L. Rodrigues, D.L. Fischman, and R.W. Waller. 2004. Status and trends of amphibian declines and extinctions worldwide. Science 306: 1783-1786. https://doi.org/10.1126/science.1103538.

Thomas, A. and S.D. Biju. 2015. Tadpole consumption is a direct threat to the endangered Purple Frog, Nasikabatrachus sahyadrensis. Salamandra 51: 252-258.

Whitaker, R. and A. Captain. 2008. Snakes of India -The Field Guide. Draco Books, Chennai, India. 